Article

\title{
Flipping the Tortilla: Social-Ecological Innovations and Traditional Ecological Knowledge for More Sustainable Agri-Food Systems in Spain
}

\author{
Leonie Guerrero Lara ${ }^{1}\left(\mathbb{D}\right.$, Laura M. Pereira ${ }^{2,3} \mathbb{D}$, Federica Ravera ${ }^{4,5, *}$ and \\ Amanda Jiménez-Aceituno ${ }^{1}$ (D) \\ 1 Stockholm Resilience Centre, Stockholm University, 10405 Stockholm, Sweden; \\ leonie.guerrero@posteo.de (L.G.L.); amanda.jimenez@su.se (A.J.-A.) \\ 2 Centre for Food Policy, City University of London; Northampton Square, London EC1V 0HB, UK; \\ laura.pereira@city.ac.uk \\ 3 Centre for Complex Systems in Transition, Stellenbosch University, 19 Jonkershoek Rd, Mostertsdrift, \\ Stellenbosch, 7600, South Africa \\ 4 Agroecology and Food Systems, University of Vic-Central University of Catalonia (UVic-UCC); \\ C. de la Laura, 13, 08500 Vic, Spain \\ 5 FRACTAL collective, San Remigio 2, 28022 Madrid, Spain \\ * Correspondence: federica.ravera@uvic.cat; Tel.: +34-605-430-235
}

Received: 14 November 2018; Accepted: 20 February 2019; Published: 26 February 2019

\begin{abstract}
The conventional dominant global agri-food system is a main driver in the Anthropocene: food production entails profound global environmental changes from greenhouse gas emissions to biodiversity loss, and shifting diets further impact planetary and human health. Innovative approaches are needed to shift towards more sustainable, equitable and healthy agri-food systems. Building on the increasing recognition of the relevance of traditional agroecological knowledge (TAeK) in sustainable food systems, this paper aims to describe innovative agri-food initiatives and explore how the use and valorization of TAeK may transform conventional agri-food systems. It employs a case-study approach in Spain, where we conducted semi-structured interviews with 12 representatives of alternative agri-food initiatives. We found that, to promote sustainable agri-food systems, TAeK has to span from farm-to-fork. Innovative agroecological practices and knowledge help to safeguard biocultural diversity, while gastronomic knowledge among consumers on how to process and prepare local varieties and species is crucial for the implementation of shorter value chains. We discuss how TAeK enhances the success of conventional systems of innovation, challenging dominant epistemological frameworks. By scaling deep (changing values), scaling out (dissemination, reproduction) and scaling up (changing institutions), the agri-food initiatives may act on leverage points to enable broader transformation of the Spanish agri-food system.
\end{abstract}

Keywords: transformations; local initiatives; sustainability; scaling; social-ecological systems; gastronomy; traditional agroecological knowledge

\section{Introduction}

The current intensive agri-food system model dominated by agri-businesses is one of the main drivers of the Anthropocene- the age in which humans have become the dominant force shaping the planet [1,2]. Agri-food systems comprise all food-related activities from production to consumption and disposal of food [3]. Scholars highlight the role of intensive industrial agriculture as a dominant driver of global environmental change; e.g., agriculture is the single largest source of greenhouse gases emissions [4,5]; land clearance for crop cultivation is causing an unprecedented 
habitat loss [6]; and overexploitation of commercial fish species are highly pressuring coastal ecosystems [7]. Gordon et al. [8] have found that food production has a significant impact on climate change, biogeochemical flows, biodiversity, and land system change. These are four out of nine planetary boundaries that indicate a safe operating space for humanity, and the boundaries of biodiversity and biogeochemical flows have already entered the zone of high risk, mainly due to food production $[8,9]$. Additionally, dietary habits and consumption patterns are increasingly shifting towards a diet high in animal based products and low in plants, putting further pressure on the planet, as the former are generally less calorie-efficient, more resource intensive and emit more greenhouse gases $[4,8,10]$. Besides these environmental challenges, agri-food systems also face societal challenges such as inequality and marginalization [6,11]. For example, driven by the globalization of the agri-food market, production processes and techniques have changed to favor intensified agriculture, often in the form of monocultures and at the expense of small-scale and subsistence farming [11-13]. Consequently, a transformation of the agri-food systems towards sustainability is necessary in order to ensure planetary health, which is fundamental for human wellbeing $[14,15]$.

Agroecology emerged as a scientific discipline, a movement and a practice to solve the social and environmental challenges associated with the dominant agri-food systems, shifting the emphasis from technology and markets to traditional agroecological knowledge (TAeK), social justice and food sovereignty $[16,17]$. On the one hand, agroecology as practice entails the idea that "agroecosystems should mimic the biodiversity levels and functioning of natural ecosystems", while simultaneously improving farmers' livelihood and enhancing the appreciation of their TAeK [18] (p. 34). TAeK builds from the concept of traditional ecological knowledge (TEK) and refers to a cumulative body of knowledges, practices and beliefs about the relation of a cultural group and their agroecosystem, that have evolved by adaptive processes and been handed down through generations by cultural transmission (adapted from [19]). TAeK is underpinned by agrobiodiversity: it is central to maintaining and managing ecosystems because cultural practices are often dependent on specific elements of biodiversity [20]. Despite the increasing recognition of TAeK's social-ecological importance, the word "traditional" is often associated with antiquity, inefficiency and stagnation and regarded as outdated and obsolete [21-23]. This notion does not capture TAeK as a dynamic, constantly evolving body of knowledge that could complement scientific knowledge and modern techniques [20]. In contrast to this thinking is the idea of applying TAeK innovatively in agri-food systems to provide solutions both within and outside the communities that hold said traditional knowledge [24-26]. Through this extension of TAeK into the innovation space, we argue that agroecological practices can be the foundation of certain social-ecological innovations, i.e., innovations considering the interdependence of social and ecological systems [26-28] and aimed at proposing alternatives to the current dominant uniform agri-food system.

Agroecology as a scientific discipline adopts a systemic approach and looks at all stages of the agri-food systems: production, distribution, consumption and waste management [29]. However, to date, the scientific studies on agri-food systems and TAeK have been mainly focused on production activities. Practices and knowledge of food processing (e.g., culinary skills, food transformation and conservation knowledge) have been largely overlooked by TAeK literature [30]. However such practices are crucial in order to promote sustainable and healthy diets [31,32].

Considering the rising awareness about multiple synergistic linkages between TAeK, biodiversity and resource systems such as sustainable agri-food systems [24,25,33], this paper explicitly focuses on innovative agri-food initiatives in Spain that emphasize the use of TAeK with regard to natural resources and their management, the practices and techniques of food production and processing, and the skills of food preparation and entrepreneurship. Therefore, this study aims to (a) describe the story of the initiatives from their foundation to their growth and identify innovative social-ecological approaches that some agri-food initiatives are implementing; (b) study the innovative contribution of TAeK within all agri-food chain activities from farm to fork in these initiatives; and (c) discuss how the stories of the initiatives offer opportunities for scaling the transformative impact of such TAeK-driven innovation in local agri-food systems in Spain. 


\section{Background: The Agri-food System in Spain}

The Spanish agri-food system has been profoundly altered in the last three decades: production processes and techniques have changed to favor intensified agriculture at the expense of small-scale and subsistence farming, often in the form of monocultures and overcrowding, which are increasingly degrading Spain's agro-biodiversity [34-36]. The decrease of family and subsistence farming contributes to the genetic erosion of various local species. For example, these farmers typically cultivated and exchanged local varieties, whereas intensified agricultural practices employed by industrialized farms that are oriented towards higher yields usually grow standardized varieties for which seeds are bought rather than saved [11,37]. Furthermore, the loss of agrobiodiversity is accompanied by the erosion of traditional practices and knowledge that fostered this bio-cultural diversity in the past $[34,35,38]$.

The loss of biodiversity also has implications for culinary culture, as it is an important pillar for food products that are used as ingredients for traditional recipes of the Mediterranean diet (MD) of which the Spanish food system is a constituent [39,40]. The MD, which has been shown to have synergies with both sustainability and human health [34,41], is under stress. In Spain, changes in lifestyle have triggered profound dietary changes [42-44]. For example, consumption patterns have shifted towards an increased consumption of animal food products such as meat and dairy [45], and a decreased consumption of staple foods such as cereals, potatoes and legumes [46]. Refined products were found to be replacing these staple foods and fresh products [46,47]. Simultaneously, cooking habits and skills—especially among younger women—are decreasing [31] and slow cooking techniques have been replaced by the purchase of ready-made dishes or simpler recipes [48]. This nutrition transition brings with it obesity and health risks [49-54] that manifest themselves in the form of increased food-related chronic diseases, decreased life expectancy and increasing health costs $[43,53,54]$. Due to these multiple challenges, the Spanish agri-food system is in need for transformative solutions towards sustainability; in other words: we need to 'darle la vuelta a la tortilla' ('flip the Tortilla (Spanish Omelette)'). The Spanish saying 'flipping the tortilla' refers to a radical change, usually from something negative to something positive.

\section{Methods}

\subsection{Studied Areas}

Three study regions in Spain were selected to represent a wide geographical diversity within Spain: the Autonomous Communities of Andalucía, Catalunya and Madrid. Such diversity entails biophysical and climatic diversity as well as socio-economic and cultural diversity. Both Catalonia and Andalusia have a Mediterranean climate, with relatively mild winters and very warm summers, while Madrid has a Mediterranean-continental climate, which is also characterized by very warm summers, but has colder winters [55]. Economically, Madrid is the wealthiest of the three regions, with the highest gross domestic product (GDP) per capita, followed by Catalonia, whereas Andalusia has one of the lowest GDP per capita within Spain. Moreover, Andalusia has Spain's highest unemployment rate with approximately 29\% in 2016, whereas both Madrid and Catalonia are below the Spanish average (ca. 20\%) with approximately $16 \%$ of unemployment [56]. The importance of the primary sector varies among all regions: In Madrid, the service sector is the most important, whereas Catalonia's economy relies on industry. Andalusia is the autonomous community with the biggest share of agriculture in the GDP. Agri-food systems reflect such environmental and socio-economic differences, as well as cultural diversity in the three regions, specifically around culinary culture. Andalusia's cuisine is rich in seafood and was strongly influenced by the Moors, being the capital and center of the trade routes in Spain; Madrid's cuisine has been enriched by other Spanish regions; and the Catalan cuisine is very diverse and based on products from land, sea and the mountains. 


\subsection{Sampling Design}

A two-step sample method was employed for the identification of the agri-food initiatives in each region [57] (p. 460). The choice was based on networks in place due to existing research cooperation and aimed at offering a wide geographical diversity within peninsular Spain. Such diversity entails biophysical and climatic diversity as well as culinary and socio-economic diversity. It is based on the case approach of the "Seeds of Good Anthropocenes" project that seeks to identify projects with a sustainability focus that are not yet mainstream [58]. For more information, visit: https://goodanthropocenes.net/om/. We selected a set of initiatives: (a) innovatively addressing a diversity of topics in relation to social-ecological issues around agri-food systems and fisheries; (b) operating at local scales; and (c) making use of TEK as a means to contribute to more sustainable food systems. The initial premise of the study was to look at TEK; however, we found that TAeK emerged as an important aspect of TEK from production through to consumption. We therefore have chosen primarily to use the term TAeK in this paper. We validated an initial list of initiatives with the help of two Spanish researchers and a national government policy maker, all of them specialized in the agri-food system in Spain.

Following a snowball method, interviewees were asked to provide information about other potential agri-food initiatives for inclusion in the study (see Supplementary Material 1 for an extensive list of initiatives). To evaluate if TAeK was emphasized by each initiative, documents and grey literature produced on and by the initiative was searched for the following keywords: "tradicional" (traditional), "artesano" (artisanal), "popular" (popular), "patriomonio (cultural)" (cultural) heritage, "dieta mediterránea" (Mediterranean Diet), "saberes campesinos" (farmers' knowledge). When several initiatives with a similar topical focus were found (redundancy), we prioritized those (a) where long-term relationships are in place, (b) that have not been over-researched and (c) logistically accessible. Due to time and resource constraints, a final limited number of agri-food initiatives $(\mathrm{N}=12)$ was selected for in-depth interviews mainly looking at responding to the scoping topics (i.e., innovation and TAeK), representing different types of organization (i.e., public-private partnerships, grassroots, social entrepreneurs), representing different topics/sectors of work (i.e., fishery; (agro-)biodiversity management, food waste, health and nutrition, education, gastronomy) and representing a different novelty along the activities of the agri-food system (i.e., production, transformation, commercialization, consume). This selection of initiatives is not intended to be a representative sample, but to offer a broad enough suite of initiatives to answer the three research questions in qualitative rather than quantitative depth, and to set up further research in this area.

\subsection{Data Collection and Analysis}

Between October and December 2017, face-to-face semi-structured interviews that lasted between $45 \mathrm{~min}$ and $2 \mathrm{~h} 20 \mathrm{~min}$ were conducted with key informants of the 12 selected seeds. All interviews were conducted in Spanish. The interview guide was divided into four main blocks: (1) exploring the main characteristics (organizational structure, activities along the agri-food system) of the initiatives; (2) telling the story of the initiative, covering its foundation (phase of seeding and germination) to the development of the initiative (phase of plant growth); (3) describing the emerging innovative features of the initiative (including aspects of inclusivity and gender) and the sources, use and transmission of traditional ecological knowledge; (4) future perspectives (see Supplementary Material 2). To define the phases of the initiatives, we adapted the phases and theory of change of the Seeds of Good Anthropocences project [58,59].

All interviews were coded in the original language, Spanish, to minimize potential bias. A mixed, inductive and deductive coding approach was chosen, ensuring flexibility for the emergence of new, unexpected topics $[57,60]$. The categories were refined iteratively by drawing out recurring themes and keywords during the coding process. The interviews were consequently analyzed with qualitative content analysis using qualitative data analysis and research software Atlas.ti (Altas.ti Scientific Software Development GmbH, Berlin, Germany) (version 8.1.0). For block 1 and 2 of the questionnaire, we mainly collected and analyzed information on their history, enabling factors for 
foundation, barriers and enabling factors, as well on their organizational structures and type of agri-food activities. For block 3 of the questionnaire, we analyzed how the agri-food initiatives are implementing and using TAeK by identifying their different practices, values and beliefs along the different stages of activities within the food chain and assessing their innovative features. The fourth block was designed as the initial preparation of a workshop of future scenarios that was not finally realized due to resource constraints, and so the information was not used for this study.

\section{Results}

\subsection{Main Characteristics of Agri-Food Initiatives}

The agri-food initiatives vary in their year of establishment from 1982 to 2015 (Figure 1). They have shown three types of organizational structure: grassroots, social entrepreneurship and public-private partnerships. Grassroots include associations, collectives, clubs and non-profit organizations. Social entrepreneurs are companies that have strong social and ecological components that are core to their companies' mission. Finally, public-private partnerships are initiatives that emerge from collaborations between the public and private sector.

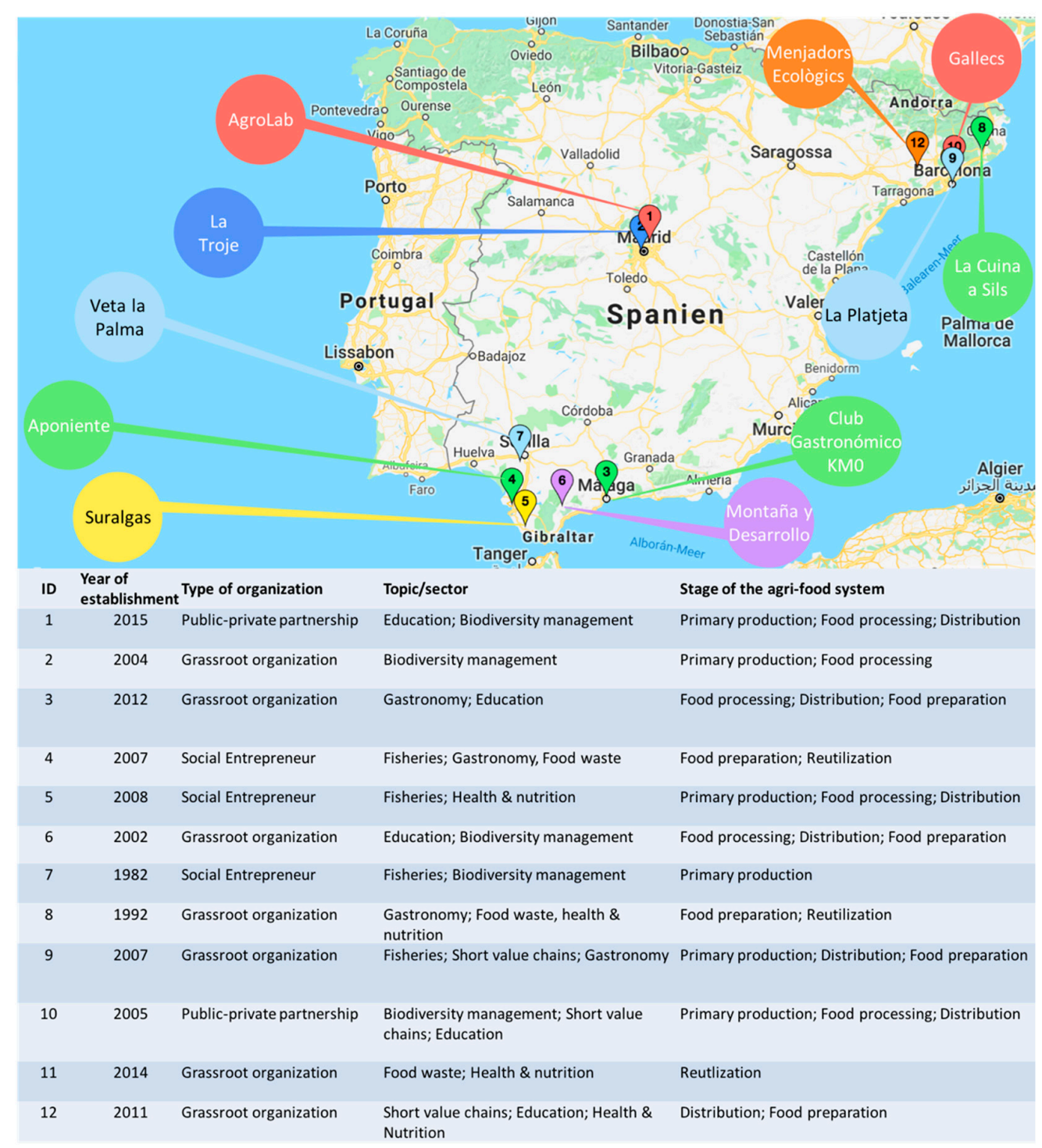

Figure 1. Infographic presenting the distribution of the initiatives along Spain, year of establishment, type of organizational structure, main reoccurring topic and the addressed stage of the food system. The ID of each initiative corresponds to the number of the interviews. 
A large number of initiatives (10 out of 12) have taken a holistic approach to the agri-food system, seeking multiple entry points by addressing several stages from the consumption to the production and preparation of food (including addressing food waste).

Our initiatives addressed a wide range of topics. The main reoccurring topics were: education, biodiversity management, gastronomy, food waste, health and nutrition and short value chains. Eleven out of twelve initiatives address several of these topics simultaneously.

\subsection{The Evolution of the Agri-Food Initiatives}

Our results show a variety of stories on how the seeds started up and grew (see Table 1). This section will present these stories on the basis of the similarities and differences related to: (1) the underlying motivations and external factors driving the foundation of the seeds; (2) the barriers and enablers to growth of the initiative; and (3) what the agri-food initiatives consider to be essential for a sustainable and culturally appropriate agri-food system. For a more detailed description of the story of each initiative, their motivations, drivers, barriers and enablers, see Supplementary Material 3.

Table 1. Overview of motivations, external driving factors, barriers and enablers that helped the development of the initiatives.

\begin{tabular}{|c|c|}
\hline $\begin{array}{c}\text { Motivation } \\
\text { Social-ecological values } \\
\text { Interest in gastronomy } \\
\text { Heritage } \\
\text { Expand the business }\end{array}$ & $\begin{array}{c}\text { Driving Factors } \\
2008 \text { financial crisis } \\
\text { Growing interest in gastronomy } \\
\text { Favorable legislation and administrative support } \\
\text { by public authorities } \\
\text { Legitimated leader }\end{array}$ \\
\hline Barriers to growth & Enablers \\
\hline Existing legislation & Networking and collaboration \\
\hline Professionalization & Adaptability \\
\hline Different attitudes and motivations towards the initiative & Official external recognition \\
\hline Lack of business experience & Marketing strategies \\
\hline Society reserved towards new ideas and tastes & Dedicated team \\
\hline Rivalry and mistrust with other initiatives & Growing interest in food \\
\hline Commercialization of the concept of 'organic' & Availability of intellectual and economic resources \\
\hline
\end{tabular}

\subsubsection{Underlying Motivations (Seeding and Germination Phase)}

The founders of the seed initiatives showed three main (and usually interlinked) motivations for its foundation (Table 1): (a) improving social-ecological aspects of the environment in which they perform their activities (8 seeds); (b) materializing their interest in gastronomy and food (4 seeds); and (c) safeguarding the cultural heritage (4 seeds). On the one hand, founders with social-ecological and gastronomic motivations have usually been influenced by their professional careers or studies (e.g., being a biologist or a gastronomy journalist). On the other hand, initiatives willing to safeguard the cultural heritage are not necessarily related to the founders' profession. They aim to take on family traditions or lessons and reconfigure them to adapt to new contexts (e.g., La Platjeta or Espigoladors) or respond to a broader understanding of land heritage and cultural resistance, e.g., Parque Agrario de Gallecs in Catalunya, a project located on land previously expropriated during the Francoist dictatorship.

One of the seeds, Veta la Palma, does not fit under any of these categories, but constitutes an example of how sustainable initiatives related to food can also derive from commercial decisions under the proper legal circumstances. In this case, a big rice company, having bought some land for cultivation, discovered that it was under environmental protection status. This circumstance pushed the transformation of their business model towards other more sustainable options.

There are different external factors driving the emergence of these seeds (Table 1): 
(a) 2008 financial crisis: the crisis is mentioned as a trigger for the creation of 3 seeds. On the one hand, it generated severe unemployment in Spain, enabling a skilled population with plenty of available time to invest in new projects, usually requiring a reinvention of their previous knowledge. On the other hand, according to the intervieewes, the crisis also fostered a growing interest for local consumption, a more collaborative spirit in the agro-alimentary sector, as well as a return to the countryside (i.e., an increased appreciation for the rural areas and migrations of young people from the city to small villages, which are strongly related to primary production processes). However, despite the crisis being mentioned as a factor that contributed to the foundation of some seeds, it has also been mentioned as a barrier for the consolidation of some seeds.

(b) Growing interest in gastronomy: 2 of the seeds mentioned that food and cooking have become really popular, which is reflected through the variety of social media posts, gastronomy societies and TV shows around food, as well as the emergence of a new generation of recognized vanguardist chefs. However, these initiatives perceive that while there is big interest in the vanguard cuisine, there is also a tiredness with this kind of cuisine and a return to the traditional cuisine:

$$
\begin{aligned}
& \text { "... a rising interest of the people for gastronomy. In Spain, we lived this effervescence of the } \\
& \text { vanguard cuisine. But then there came a moment when the people got tired of it and needed to } \\
& \text { comeback to something more authentic and familiar." [Interview 3] }
\end{aligned}
$$

(c) Favorable legislation and administrative support by public authorities: 3 of the seeds mentioned legislation favoring their initiatives and administrative support from public authorities as important enabling conditions to start and get legally consolidated.

(d) Legitimated leader: In one case, the agroecological parc of Gallecs, the presence of a leading figure originating from the territory was essential for legitimization of the initiative's actions among the local community.

\subsubsection{Barriers and Enablers (Growth Phase)}

\section{Barriers}

There are a large number of barriers that the initiatives are encountering, but two main challenges stand out: that of unfavorable existing legislation and professionalization of the initiative. Below is a short summary of the main barriers discussed by the initiatives.

(a) Existing legislation: A barrier mentioned by half of all initiatives is that of existing legislation that either directly restricts the impact of the initiatives or is contradictory. One example of a legal barrier is that of public procurement that must be price competitive, but not quality oriented. For example, in the case of Menjadors Ecològics, this restricts the initiative's work when aiming to change school menus towards more sustainable and healthy options. Another example are the legal requirements for seed production that are designed for large seed companies, which contradicts legislation on access and benefit sharing for the holders of indigenous and local knowledge.

(b) Professionalization: A common barrier is professionalizing the initiative and making a living from their activity (6 seeds). This barrier is often found in combination with a lack of funding and/or the difficulty to juggle both family and professional life. It is particularly challenging in times of crisis.

(c) Different motivations by members: Differing opinions can cause conflicts and result in a barrier for the initiative ( 3 seeds). For example, some members are passionate about their work and perform it despite having a low or no salary at all, whereas others see it more as their work and are not willing to fully commit without financial compensation.

(d) Lack of business experience: For two initiatives among the social entrepreneurs, the lack of experience in business development resulted in problems, as they have to learn along the way and are more likely to make mistakes. 
(e) Society reserved towards new ideas and tastes: Among the gastronomic initiatives, two have stated that they have encountered difficulties because the majority of society does not easily accept new ideas and tastes.

(f) Rivalry and mistrust with other initiatives: Two seed initiatives mention that rivalry and mistrust with other initiatives or institutions of the same sector is hindering their work. This barrier is linked to other networks in place that, if cooperation is not successful, can result in competition.

(g) Commercialization of the concept "organic": Although some initiatives consider that the growing interest in local and organic food has enabled their foundation, others suspect the commercialization of the concept "organic" and "local varieties" from both supermarkets and restaurants:

"When we started in the villages, nobody was interested. We organized samples because we went there, but the municipalities ignored us. But now they call us and want us to do samples of tomatoes, super luxury restaurants call us and want local tomato varieties. [ ... ] Suddenly they value it as something that differentiates, that gives additional value. Suddenly, it makes sense in their discourse. [ ... ] But we sometimes mistrust this, because there could be different trends in the future [... ] In other words, we cannot trust this trend." [Interview 2]

\section{Enablers}

We have identified six different factors that enabled the consolidation and growth of the initiatives after the initial phase. There are differences that apply more generally to the agri-food initiatives such as networking and adaptability and other factors that differ according to the stage of the agri-food system in which an initiative finds itself, such as official external recognition, marketing strategies and growing interest in food.

(a) Networking and collaboration: the importance of getting support from a wider net of agri-food practitioners as well as from the surrounding communities were important aspects mentioned by 5 of the seeds.

(b) Adaptability: Some (4) initiatives highlight the need to be able to adapt. Specifically, they refer to the ability of the initiatives to analyze their activities and quickly change strategy or organizational structure if what they do is not working.

(c) Official external recognition: All initiatives whose main activity is the preparation of food stated that the official external recognition in the form of certificates, awards or media attention can also enhance their success. These signal to consumers high quality and safety of the food.

(d) Marketing strategies: For three of the production related initiatives, novel and successful marketing strategies significantly fostered their growth. Such strategies include communicating to the consumers the additional social and environmental value of their product or commercialization model.

(e) Dedicated team: Two seed initiatives also highlight the importance of having a dedicated team that is committed to their goals despite difficulties and shortage of money. This is important to keep the initiative going especially in tough times.

(f) Growing interest in food: Finally, one initiative, La Cuina a Sils, perceived the growing interest in food as a consolidating factor.

(g) Availability of intellectual and economic resources: 7 of the 12 seeds mentioned that having extensive previous knowledge of the work area (e.g., through studies identifying local needs or the founder having extensive knowledge of the context) and access to funding were important. Regarding funding, the case of Veta la Palma is interesting, who highlights the availability of large financial resources and being a consolidated company as the main enabling factor to create an innovative and sustainable seed, which was known not to be profitable in the short term. 


\subsubsection{Underlying Values Once the Initiatives Have Grown}

The different values brought up during the interviews indicate what the agri-food initiatives consider to be essential for a sustainable and culturally appropriate agri-food system:

- Connection between local production and consumption and between people, their food and each other (7 out of 12 interviewees), "[we value] the capacity of the cuisine to connect. For example, for our activities, we always put long tables where everybody sits together." [Interview 3]

- environmentally friendly production (6 out of 12 interviewees), "producing fish, in these physical conditions and in turn, contributing to improve the environment" [Interview 7]

- and the preservation of traditional consumption patterns (6 out of 12 interviewees), "I create a demand for a product that was disappearing. I safeguard the traditional cuisine to promote a diversification and maintenance of local varieties." [Interview 3]

Moreover, the agri-food initiatives envision an agri-food system that

- dynamizes rural areas (4 out of 12 interviewees), "our main goal is to dynamize rural areas through the agrarian sector by fostering sustainable practices that promote agricultural landscapes, the participation by the community. This is a way to empower the local communities and establish urban-rural relationships." [Interview 1]

- places value on food producers (7 out of 12 interviewees), "We are placing value on activities that the farmer's life comprises - we are placing value on it, since a great majority [of the population] does not do [value] it" [Interview 6]"

- $\quad$ promotes human health (5 out of 12 interviewees), "We recover the Mediterranean diet because it is a balanced diet" [Interview 12].

- and is based on natural products (3 out of 12 interviewees) instead of processed convenience food that aims at optimizing the ease of consumption, "healthy, natural products, less altered, more nurturing. Because nowadays there are many products with empty nutrients." [Interview 5]

However, it is hard to assess whether the promotion of these values is successful. Some initiatives connect the consumers' willingness to pay a higher price for the product to the successful shift of food values:

"A greater appreciation and respect for the traditional cuisine and for its products. A disposition/willingness of the consumer to search for and pay the local product. If it is more expensive, I am willing to pay more, as I value it. It's an appreciation." [Interview 3]

\subsection{TAeK-Driven Innovation in Local Agri-Food Systems From Farm-To-Fork}

Our results show how TAeK practices are used by the agri-food initiatives along the different stages of activities within the food chain (from farm-to-fork) as means to contribute to more sustainable agri-food systems. Table 2 illustrates the novelty of the initiatives selected, with specific emphasis to TAeK. 
Table 2. Innovative traditional agroecological knowledge (TaeK) features of the initiatives from farm to fork.

\begin{tabular}{|c|c|c|c|}
\hline Initiative & Stage & Innovative Feature & Link to TAeK \\
\hline AgroLab & Farm & $\begin{array}{l}\text { Offers practice-oriented agricultural training for people } \\
\text { interested in working within agriculture, as a new way of } \\
\text { integrating people at risk of social exclusion to the labor } \\
\text { market and establishing urban-rural connections. }\end{array}$ & $\begin{array}{l}\text { Hybridizes different types of } \\
\text { knowledge and recovers } \\
\text { traditional farming techniques } \\
\text { when useful. }\end{array}$ \\
\hline $\begin{array}{l}\text { Asociación La } \\
\text { Troje }\end{array}$ & Farm & $\begin{array}{l}\text { Meets the loss of agrobiodiversity, specifically of local seed } \\
\text { varieties in Madrid and fosters the reappraisal and } \\
\text { intergenerational transmission of traditional knowledge. }\end{array}$ & $\begin{array}{l}\text { Collects old seed varieties and } \\
\text { the associated traditional } \\
\text { knowledge. }\end{array}$ \\
\hline $\begin{array}{l}\text { Club } \\
\text { Gastronómico } \\
\text { KM0 }\end{array}$ & Fork & $\begin{array}{l}\text { Promotes local consumption by establishing alliances } \\
\text { between small-scale farmers and consumers; safeguarding } \\
\text { traditional recipes and disseminating the local culinary } \\
\text { culture. Highlights the role of women in the } \\
\text { intergenerational transmission of culinary knowledge. } \\
\text { Fosters employment for women at risk of social exclusion } \\
\text { by making use of their traditional culinary knowledge. }\end{array}$ & $\begin{array}{l}\text { Safeguards traditional recipes } \\
\text { and sharing the local culinary } \\
\text { culture. }\end{array}$ \\
\hline Aponiente & Fork & $\begin{array}{l}\text { A Michelin 3-stars seafood restaurant. The plates served } \\
\text { are based on discarded fish and less valued species and } \\
\text { phytoplankton. It shows alternatives to the consumption } \\
\text { of big species. }\end{array}$ & $\begin{array}{l}\text { Offers modern versions of } \\
\text { traditional plates and tastes. }\end{array}$ \\
\hline Suralgas & Fork & $\begin{array}{l}\text { Harvests algae for human consumption incorporating it } \\
\text { into the traditional cuisine. It promotes a plant-based } \\
\text { alternative protein source. }\end{array}$ & $\begin{array}{l}\text { Incorporates a new product into } \\
\text { the traditional cuisine. }\end{array}$ \\
\hline $\begin{array}{l}\text { Asociación } \\
\text { Montaña y } \\
\text { Desarrollo }\end{array}$ & Farm & $\begin{array}{l}\text { Fosters educative projects in rural areas focussing on and } \\
\text { recovering popular culture with a feminist approach as a } \\
\text { tool for sustainable development. Combines exchanging } \\
\text { seed varieties and including women by their feminist } \\
\text { working group (FEMINARIO). }\end{array}$ & $\begin{array}{l}\text { Safeguards old varieties and } \\
\text { farming techniques and } \\
\text { disseminates of the popular } \\
\text { culture. }\end{array}$ \\
\hline Veta La Palma & Farm & $\begin{array}{l}\text { Fish farm within the Doñana National Park. It functions as } \\
\text { a shelter for migrating birds and has significantly } \\
\text { increased biodiversity. It creates employment for local } \\
\text { fishers by using traditional fishing techniques. }\end{array}$ & $\begin{array}{l}\text { Uses traditional fishing } \\
\text { techniques and knowledge. }\end{array}$ \\
\hline $\begin{array}{l}\text { La Cuina a } \\
\text { Sils }\end{array}$ & Fork & $\begin{array}{l}\text { Promotes left-over recipes to reduce food waste. It is a } \\
\text { collective of senior women trying to preserve the } \\
\text { traditional cuisine of Sils, Catalunya. }\end{array}$ & $\begin{array}{l}\text { Safeguards traditional recipes } \\
\text { and disseminates the local } \\
\text { culinary culture. }\end{array}$ \\
\hline La Platjeta & $\begin{array}{l}\text { Farm } \\
\text { and } \\
\text { Fork }\end{array}$ & $\begin{array}{l}\text { Offers fish baskets with seasonal fish that are delivered to } \\
\text { the home of the consumers. It reduces fishing pressures on } \\
\text { overfished species. It offers activities related to fishery to } \\
\text { promote the cultural heritage of the artisanal fishers in } \\
\text { Barcelona. }\end{array}$ & $\begin{array}{l}\text { Uses traditional fishing } \\
\text { techniques, targeting of } \\
\text { forgotten species and promotion } \\
\text { of the cultural heritage of the } \\
\text { artisanal fishers. }\end{array}$ \\
\hline $\begin{array}{l}\text { Parque } \\
\text { agrario de } \\
\text { Gallecs }\end{array}$ & Farm & $\begin{array}{l}\text { Agroecological park managed by a consortium of different } \\
\text { municipalities. It fosters agrobiodiversity by recovering } \\
\text { local varieties, fostering short marketing circuits and the } \\
\text { reconversion of the area to organic farming. }\end{array}$ & $\begin{array}{l}\text { Recovers old varieties and } \\
\text { farming techniques. }\end{array}$ \\
\hline Espigoladors & $\begin{array}{l}\text { Farm } \\
\text { and } \\
\text { Fork }\end{array}$ & $\begin{array}{l}\text { Targets food waste, making healthy diets accessible for } \\
\text { people at risk of social exclusion and creating new job } \\
\text { opportunities. It establishes cooperation with farmers to } \\
\text { glean fruit and vegetables that otherwise would remain on } \\
\text { the field. It donates } 90 \% \text { of the gleaned food to soup } \\
\text { kitchens and elaborates marmalades and cream with the } \\
\text { remaining 10\% for which people at risk of social exclusion } \\
\text { are employed. }\end{array}$ & $\begin{array}{l}\text { Re-invents the gleaning } \\
\text { tradition: the poor were } \\
\text { traditionally given access to the } \\
\text { fields after harvest, so that they } \\
\text { could collect what had been left } \\
\text { on the field. }\end{array}$ \\
\hline $\begin{array}{l}\text { Menjadors } \\
\text { Ecològics }\end{array}$ & Fork & $\begin{array}{c}\text { Establishes direct links with school canteens to help them } \\
\text { shift towards a traditional diet based on local organic } \\
\text { varieties and products. }\end{array}$ & $\begin{array}{l}\text { Recovers the Mediterranean } \\
\text { diet. }\end{array}$ \\
\hline
\end{tabular}

\subsubsection{On Farm: Maintaining Agrobiodiversity and an Opportunity for Social Inclusion}

TAeK offers an opportunity to maintain agrobiodiversity by using traditional seed selection and exchange processes. Agricultural production initiatives take over the role of TAeK-holders (i.e., people 
that are knowledgeable about and make use of traditional practices), safeguarding local seed varieties, as well as the knowledge and practices related to seed production, selection and exchange processes.

"they [seed varieties] have all the history of selection and they can still be adapted to new necessities.

Those varieties have a large genetic diversity/richness." [Interview 2]

Through traditional seed selection processes, the local seed varieties are creatively adjusted to the environment and climate in order to be suitable for today's necessities:

"Apply all these seed varieties and the traditional knowledge that we have collected to agriculture so that it makes sense at present. Adapt it ... select it for the necessities we have today. A mix of the legacy that we have collected, but also using it without leaving it [the knowledge and the seeds] static." [Interview 2]

Here, adaptation refers to seed selection processes and the exchange of seeds with other similar initiatives in other regions, e.g., via the national seed-exchange network, called "Red de Semillas". This is a mechanism to respond to the changing environmental conditions and, in particular, the experience of climate change within available, often scarce resources. It seeks to modify or find traditional varieties from other regions that are better suited for the environment.

As well as being able to maintain ecological diversity, the knowledge associated with diverse farming practices provides an opportunity for social inclusion. The interviews show that the presence of TAeK can lead to the creation of jobs for marginalized TAeK-holders. By utilizing TAeK in the workplace, TAeK-holders can qualify for jobs even without having high formal education, which is often a barrier to the labor market and makes those lacking it susceptible to social exclusion.

"We import from here the knowledge that the people have and their capacity concerning the activities related to aquaculture [..] We use people for labor that are already familiar, if not with the same, with similar activities [...] we make people see that the knowledge they are holding, fishing knowledge, how to braid nets, knowledge of whatever, really can be applied e.g., within aquaculture. If traditional fishing has been in detriment due to the changes in the river, we can still grow/cultivate fish. And we can grow them in the same environment, with good, reasonable principles and moreover, we can grow them using ancestral knowledge." [Interview 7]

Additionally, two initiatives offer educational programs to open new possibilities in typically marginalized rural areas for people at risk of social inclusion, by passing on essential knowledge and skills to independently carrying out farming activities. They further highlight the need to address gender dynamics where women can be disenfranchised:

"It is an innovation to consider the rural environment as a transversal space were a lot of things can be addressed, from producing and safeguarding traditional varieties to being a socially inclusive space. [...] Because of the masculinization of rural environments we want a high representation of women and give them their own space." [Interview 1]

Such informal educational programs complement formal educational programs by having different focuses and by paying special attention to the needs of women.

"We drive educational processes in rural environments, education of popular culture and traditional knowledge. [...] It's very innovative to take a stance for feminism. It's not usual in the rural environment." [Interview 6]

\subsubsection{To Fork: Innovating Marketing, Culinary Knowledge and Taste Preferences, and 'Espigar'}

Our results show that an absence of culinary knowledge can be a barrier to healthy and sustainable diets. For example, local varieties, though tasty, are currently not very profitable or easy to sell through conventional markets due to their appearance or simply the unfamiliarity of consumers with them 
and the lack of knowledge and skills to prepare them. Then, culinary knowledge is understood by the initiatives as holistic knowledge, composed of different steps that are often linked. First, in order to consume local varieties, consumers need to know what products are seasonally available. One way to address this is through innovative marketing of baskets with seasonal and local products: "We realized that the people did not know what fish to order, therefore, we invented the fish baskets, so that the people that did not know what to order could have/buy seasonal fish [Interview 9]." Another example is selling locally branded products: "By creating our own brand for local, ecological products a lot of doors opened up. It was a way to communicate Gallecs through our products" [Interview 10]. Consequently, consumers need to be able to assess the quality and freshness of the "new" products. The interviews revealed that the lack of gastronomic TAeK among consumers on local varieties can present a barrier for shorter value chains that commercialize these local varieties and species. Shorter value chains were pursued by the initiatives on the one hand as a means to successfully bypass intermediaries that concentrate market power and therefore pressure producers, and on the other hand to reduce food miles:

"The fact that last year, 10 tons of vegetables remained in the Maresme region and were distributed to schools less than $10 \mathrm{~km}$ away, that's an impact [...] and also, that the farmers have a guarantee for a large share of their annual harvest" [Interview 12]

Second, consumers also need to know how to process the primary product they have purchased, e.g., how to fillet a fish or what type of tomato is best suited for what purpose, e.g., for salads or for tomato sauce: "Then, following this [the invention of fish baskets], we realized that the people needed information. Know what type of fish, how to fillet it, how to cook it " [Interview 9]. The purchase of processed products (e.g., filleted fish) makes it difficult to assess the quality of the primary product. However, by responding to the needs of consumers, this step can potentially be substituted. For example, initially 'La Platjeta' started by offering fish filleting workshops, but as not all consumers were responsive to the workshops, they are now also offering filleted fish in their fish baskets. Finally, cooking skills are important: only if consumers know how to cook the food themselves can they buy fresh produce direct from fishers and farmers rather than ready-made meals. Several initiatives aim to provide this knowledge via cooking workshops, cooking books, and online recipes.

A similar example is the lack of taste formation among children. Today, many children are served ready-made meals at home and therefore not used to eating plates based on lots of fresh, seasonal vegetables and might not like these at first:

"Of course, at school, in the canteen, when you want to change tastes [it is difficult], people are not used to the taste of, for example, beetroot." [Interview 12]

Therefore, Menjadors Ecològics, an initiative that connects school canteens with local producers and helps to adjust the menu to the Mediterranean diet, reports that changing children's tastes is pursued gradually. The school menu gradually adopts local varieties that are sometimes unfamiliar for the children. If the children are successfully accustomed to the taste of local varieties and the dishes prepared with them, it can influence the food culture within the family:

"It's interesting to work with schools, if the children like the food, they will ask their parents to cook it." [Interview 12]

The presence of gastronomic TAeK also entails an opportunity for introducing novel products that are compatible with traditional taste and cooking techniques. For example, two initiatives, Suralgas and Aponiente, are working with novel algae products and phytoplankton as alternative protein sources in Andalusia:

\section{"[...] such an innovative product in the Andalusian diet or the Mediterranean gastronomy is becoming a proper product of the diet." [Interview 5]}

The case of algae and phytoplankton is particularly interesting from a sustainability perspective as they do not require high inputs of water and land for their production, are plant-based, high in protein and moreover species with a high reproduction rate that therefore allow a low impact harvest: 
"With phytoplankton we are promoting/fostering the consumption of a species with a very high reproduction rate" [Interview 4]

Both initiatives reported that their products have the potential to be accepted by a large number of people, as the taste of the algae is compatible with the "architecture" of the traditional cuisine. Novel products can thus enrich the traditional cuisine, but maintain its essence. It is important that these changes are understood as an enrichment rather than a replacement of the tradition, as pointed out in one of the interviews:

"In the beginning, some people were saying: Look at him. What does he try to set up with marine ingredients, here where we have such good fried fish and seafood dishes? What does he pretend to innovate?" [Interview 4]

Interestingly, one initiative reported that the acceptance of algae as a new product varied in different regions in Spain, which was explained by the different regional culinary cultures. According to the interview, there is an opportunity for the introduction of algae in regions that are more accustomed to the 'taste of the sea' and are familiar with culinary techniques that could be adapted to the preparation of algae. In regions where the culinary culture is not linked to sea products, the absence of culinary knowledge was found to be a barrier to customer acceptance of algae-based products. Thus, the presence of gastronomic TAeK among consumers can determine the acceptance and the success of novel products.

Finally, the tradition of "Espigar" offers a means to tackle food waste. Originally, "espigar" ('gleaning') referred to the 'second harvest', meaning the harvest of leftover grains. Landowners gave permission to poor people to look for vegetables after the main harvest was done. The initiative Espigoladors (or 'gleaners') adjusted this concept to the present: they contact farmers and ask them for permission to harvest their fields whenever the harvest would remain unused on the field due to low market prices or because the food is a bit too ripe. For this activity, volunteers are recruited. The products are then donated to soup kitchens. The tradition of gleaning has been adapted in a process of bricolage to fit today's challenge of waste in the agri-food system. However, the aim remains the same: providing healthy quality food for marginalized people. Moreover, gleaning offers an opportunity to significantly reduce food waste within primary production:

"By gleaning you solve the problem of food waste on the field. Until now, primary products were not recovered from fields." [Interview 11]

\section{Discussion}

\subsection{Patterns of the Emergence and Development of the Agri-Food Initiatives}

Our result showed a variety of enabling factors for the foundation of the initiatives, as well as many barriers and consolidation factors that influenced how the initiatives developed. Below, we highlight and discuss those that affected a large number of initiatives and those that we found particularly interesting. The 2008 crisis as well as favorable changes in policy can be considered as windows of opportunity for the emergence of some seeds. Windows of opportunities in resilience and transformation literature have been mostly highlighted as an important condition for navigating the transition towards alternative system states [59,61,62]. However, our study indicates the importance of windows of opportunity for facilitating the emergence of new initiatives. All initiatives that took advantage of a window of opportunity had extensive previous knowledge of the context and/or essential skills for running the initiatives. Further, networking and the growing interest in gastronomy were mentioned by the initiatives as both enabling and consolidating factors. However, we found interesting differences. For example, the type of networks that supports their consolidation differs from the one that enables the foundation of the initiative. The latter is more of a local nature, whereas the former often refers to umbrella networks of similar initiatives. This resonates with the finding 
of other (grassroots) innovation scholars that has highlighted the importance of horizontal networks to expand their impact [63]. Such networks can provide support, facilitate learning and knowledge exchange and gain momentum for the same cause. In relation to the growing interest in gastronomy, the difference in whether it is a consolidating or enabling factor can be explained by the age of the seed. For example, La Cuina a Sils was founded already in 1992 and so the rising interest in gastronomy, reflected in its media attention, has been a boost for the initiatve in recent years whereas other, younger seeds, have used the growing gastronomy movement as a driver to establish a new initiative. We found that the agri-food initiatives face diverse barriers of both external and internal nature. Whereas the most common barrier, existing legislation, is clearly external and caused by the current design of the system, the initiatives also face the challenges of a number of barriers that are rather a product of internal dynamics, such as different motivations and attitudes towards the initiatives by their members and rivalry with other initiatives.

\subsection{Overcoming Barriers and Leveraging Opportunities for Scaling the Impact of Agri-Food Initiatives for Sustainable Transformations of the Agri-Food System}

The transformation of the Spanish agri-food system towards sustainability cannot emerge from isolated small-scale experiments, but requires scaling of the impacts and approaches of the agri-food initiatives presented above. The story of the agri-food initiatives, their values, the barriers they are facing, as well as the factors that help them consolidate significantly affect their scalability and consequently their impact in the larger agri-food system. Below, we discuss and situate our research findings from sections 4.1.2 and 4.1.3 with the help of the three scaling strategies adapted from Moore et al. (2015) [64]. Scaling processes can be grouped into: scaling deep (changing values and minds), scaling out (expanding impacts or replicating) and scaling up (changing rules, norms and legislation) [64]. From this scaling perspective, innovative agroecological approaches are interesting as they have a significant advantage: drawing on centuries of TAeK, they require low inputs [37].

\subsubsection{Scaling Deep: Changing Agri-Food Related Values}

Long-lasting change can only be achieved "when people's hearts and minds, their values and cultural practices, and the quality of relationships they have, are transformed" [60] (p. 12). In this sense, the agri-food initiatives in this study explicitly aim to enhance values that are currently marginalized in agri-food systems. A previous study by Gómez-Cantó et al. [65] that assessed food values among consumers in Spain supports the initiatives' perception that the values they are promoting are not being regarded as very important by Spanish consumers. The same study determined taste, safety, price and appearance of the product as the most valued attributes of food among Spanish consumers. When comparing their findings with the values that the agri-food initiatives are seeking to promote, it becomes evident that the initiatives are trying to revalorize those values that are currently the least important for the consumers (e.g., origin, environmental impact or tradition), and which are linked to traditional food production (see Supplementary Material 4). The initiatives therefore place great importance on the cultural dimension and on the concept of local food. Thus, agri-food initiatives can challenge and enrich current narratives of sustainable agri-food systems that at the moment are limited to food security for present and future generations as proposed by the Food and Agriculture Organization of the United Nations and the United Nations Enviroment Programme [66]. This is particularly relevant, as they can jointly fuel articulation of new meta-narratives and values that open pathways towards sustainability transformations [67].

However, despite the wide recognition of the importance of values when envisioning a transformation towards sustainability $[14,64,68]$, the impact of the promoted values might be limited for three reasons. First, it is hard to assess whether the promotion of these values is successful. Second, it remains uncertain that pro-environmental values and attitudes will lead to sustainable lifestyles [68]. Some food-related studies have found that sustainable values increase the likelihood of buying products that are consistent with these values, whereas other have reported a so-called 
attitude-behavior intention gap [69]. Such an attitude-behavior gap describes behavior that is not consistent with verbal claims [70]. Therefore, a shift in values alone is not sufficient, but needs to be combined with institutional structures that make it easy for people to make sustainable food choices [68,70].

Third, despite a growing interest in local and organic food, big businesses are increasingly coopting organic food standards. Big players are entering the market because they want to take advantage of an existing niche. This can result in the weakening of standards and increased regulatory capture putting at risk the transformative potential of the movement [71].

\subsubsection{Scaling Out: Expanding the Impact of Local Agri-Food Initiatives}

We have identified that three different dimensions can help the initiatives grow their reach. Firstly, connecting the innovation to traditions. Traditions and culture, especially in Spain, are very important in relation to agri-food systems: diets need to be culturally sensitive and appropriate, as they constitute an important part of our cultural identity and trigger emotions, memories and pleasure [72]. Moreover, taste is culturally constructed; whether we like foods or not is influenced by what we are used to eating; thus, cultural preferences determine the acceptance of food and general wellbeing [6].

This has implications when aiming to transform and expand a more sustainable agri-food system, e.g., when introducing novel products. Thus, the introduction of algae and phytoplankton in southern Spain as plant-based substitutes for animal protein is successful because the current gastronomic traditional knowledge matches the innovative product. This aligns with Hunn's notion [73] (p. 13) that enriching and innovating traditions is possible, but requires certain rules: "[n]ew ideas and techniques may be incorporated into a given tradition, but only if they fit into the complex fabric of existing traditional practices and understandings." Thus, the vanguard cuisine is an excellent opportunity to combine and merge traditional and innovative cuisine and culinary practices, as reflected for example by the initiative Aponiente.

Secondly, the acceptance of food innovations by local communities is also a critical requirement for agri-food initiatives to be replicable. For example, the fish farm model of Veta la Palma, which is beneficial for the ecosystem while creating employment for TAeK-holders, highlighted how employing people from the community and making use of their TAeK significantly increased the acceptance of this initiative. This supports the findings of previous studies that have identified an opportunity for social-ecological innovations to take into account the potential of accessible and applicable TAeK for livelihood generation [74,75]. Moreover, this could suggest that if there is the presence of TAeK, innovations are more likely to be successful if they are culture sensitive. This is of high relevance, as currently the majority of innovation systems emphasize scientific and technological knowledge [75].

Thirdly, some initiatives highlighted the potential of novel marketing strategies to reach more people, gain more customers and grow as an organization. Such strategies aim to transmit the value of the products beyond the quality and taste the consumer is experiencing, drawing attention to its producers and environmental values. Different authors have referred to these strategies as social marketing, acknowledging them as potentially adequate for changing people's behavior towards sustainability [76,77]. While one initiative, Veta la Palma, is more focussed on promoting products with added environmental value, others also aim to change people's environmental values and behavior [78] by organizing different events and workshops. This type of strategy seems to be really important for initiatives selling their sustainable products.

\subsubsection{Scaling Up: Changing Existing Legislation in Agri-Food Systems}

The existing legislation and administrative structures in the current agri-food system hinder the success of these initiatives. This is especially relevant to agri-food initiatives that actively challenge the status quo and propose new rules and laws to facilitate their work, such as Menjadors Ecològics. Other initiatives have mentioned the need to actively advocate for new laws in the future, pointing out that they have no capacity for this at the moment. 
Scaling-up and altering the above-named legislations so that they would support the innovative activities was found to be difficult, as policy makers appear not to share the values that are driving the agri-food initiatives. Although the initiatives are trying to enhance certain food values, the value shift has a limited reach and is targeted more towards consumers than towards policy makers. Thus, the actions taken by the initiatives are very fragile and can be easily captured by conventional approaches if not being supported by a legal framework.

\subsection{TAeK-Driven Innovation}

Interdependencies between Farm and Fork TAek

Our work shows many ways in which TAeK can be relevant in contributing to a transformation towards a sustainable agri-food system. Following the Latin etymological roots "tradere" of 'traditional' knowledge which means "to transmit" or "to send", our understanding of TAeK does not only link traditions to the past, but also to the future [22]. The initiatives presented in this study clearly reflect how innovations and traditions can be merged to support sustainable agri-food systems. Thus, when re-inventing cultural heritage and traditions, the boundaries between innovation and tradition become fluid: transformative knowledge hybridizes and adapts different forms of knowledge so that they are relevant in the context of today's challenges [33,79]. Our results show that innovative TAeK in the form of practices, beliefs and values sits in different stages of the agri-food system, from farm to fork. All these forms of knowledge are interdependent, as illustrated by the knowledge tower (see Figure 2), a metaphor of the agri-food system, where each block represents a type of knowledge and depends on those around it. It is possible to take out some blocks, but after a while, if too many blocks are removed, the tower collapses, as in the game of Jenga.

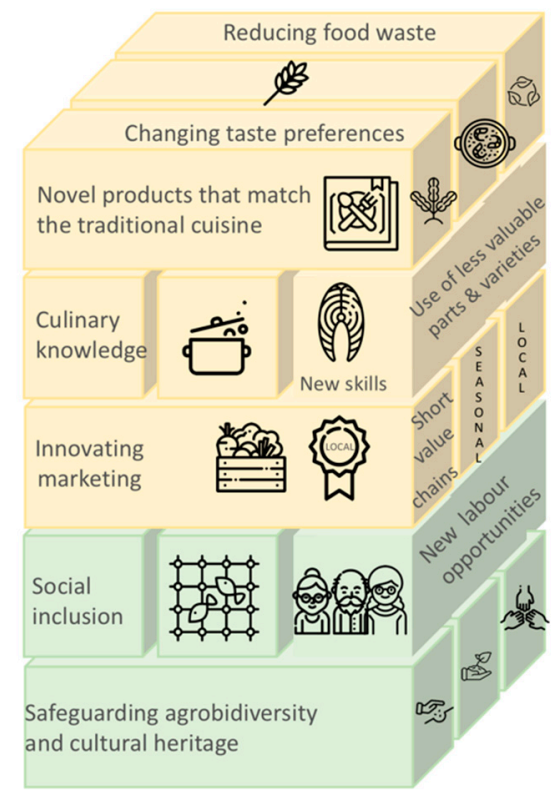

Figure 2. The knowledge tower shows where innovative TAeK in the form of practices, beliefs and values sits in different stages of the agri-food system from consumption to production, and can be held by both farm- (green) and fork-related (yellow). This is an illustrative collection of factors based on the findings of the research and not representative of all the potentially important knowledge factors. (Source: Author's own).

The knowledge at the base of the tower, innovative farm-TAeK, is crucial to foster social inclusion (e.g., focus on gender and marginal vulnerable people of many initiatives) and give stability to the agri-food system by safeguarding agrobiodiversity. These knowledge blocks include a focus on knowing and managing local varieties providing synergies with agrobiodiversity conservation 
interrelated with future adaptation processes to a changing environment, which, in the face of climate change, become more and more important $[55,56]$.

At the top of the tower, fork-related TAeK is important to shorter value chains, to introduce new products and reduce food waste, as well as to enable people to prepare and consume the products based on farm-TAeK. The fork knowledge is composed of various interconnected parts (i.e., seasonal processing, assessing quality or cooking, commercializing) and is needed to valorize local varieties, the use of less valuable parts and leftovers of agricultural products, and to insert new products that fit the traditional cuisine. For example, short value chains can help to safeguard agrobiodiversity, valorizing new products from local varieties, while minimizing food miles and empowering local producers [57]. Another example is the innovation of algae in the Spanish agri-food system, as algae has been increasingly proposed as a necessary substitute to reduce the high consumption of animal proteins and its related negative effects for human and planetary health $[43,58,59]$.

\section{Conclusion}

The Spanish agri-food system needs to 'flip the tortilla' or transform in order to respond to the sustainability challenges of the current agri-food system. By identifying and describing a set of innovative agri-food initiatives in Spain, this paper has discussed the important role that TAeK plays in enabling potential transformations towards more sustainable agri-food systems. We argue that focusing on maintaining production-related TAeK alone is not sufficient to promote local markets and safeguard the local heritage and its associated values. We therefore propose recognizing knowledge across the entire agri-food system in order to enable innovation that comes from the merging of various knowledge systems towards sustainability. We conclude that innovation must engage with all stages of the agri-food system, from farm-to-fork, to have a systemic impact. Specifically, this study showed that gastronomic TAeK is important for the successful implementation of shorter value chains, which is considered to be a key approach for sustainable agri-food systems. If the transformation of the Spanish agri-food system is to be successful, the approaches and efforts of novel agri-food initiatives need to be scaled: changing the values of the consumers toward sustainable and healthy diets, expanding and replicating successful agri-food initiatives and advocating for changing unsuitable legislation. Likewise, if the innovative approaches presented in this study are to scale appropriately, they need to be adapted to the context, as TAeK is embedded in the local culture.

Finally, this paper contributes to a new understanding of how TAeK is a form of innovation, and emphasizes that novelty does not mean to reject tradition; rather, it is important to recognize the potentially transformative knowledge that comes from traditional practices, which can be reconfigured to be relevant in a forward-looking context. As well as emphasizing how TAeK can be combined as innovation towards transformative change, the paper also interrogates how different forms of scaling these innovations are appropriate for different circumstances and can result in different types of impacts necessary for moving towards more sustainable agri-food systems. Rather than a manual for a step-by-step replication, this study can be an inspiration on how TAeK can be relevant as innovation for present and future agri-food systems in diverse contexts.

Supplementary Materials: The following are available online at http://www.mdpi.com/2071-1050/11/5/1222/s1, Excel S1: Initial list of initiatives, Document S2: Interview guide, Table S3: Story of the initiatives; Figure S4: Value change.

Author Contributions: L.G.L. with the help of L.P. and F.R. conceptualized the article; L.G.L., F.R. and L.P. were involved in the methodology design; data collection was carried out by L.G.L.; data analysis was performed by L.G.L. with help of A.J.-A., L.P. and F.R.; L.P. and F.R. acted as supervisors of the Master thesis. A.J.-A. examined the thesis and provided relevant feedback how to improve it; visualization were developed by L.G.L.; L.G.L. did the writing-original draft preparation and lead the writing of the paper; all authors contributed to the writing-reviewing and editing of the manuscript.

Funding: The fieldwork of this research was funded by the Stockholm Resilience Centre. For realization of this work the corresponding author received funds by the Ministry of Economy, Industry and Competitiveness (Spain) (IJCI-2015-25586) and AXA Research Fund for the project AGATA (www.agata.cat) (2017-2019). The project ADAPTAL El rol del conocimiento tradicional agrario y alimentario en la adaptación al cambio climático 
(CSO-2016- SPID201600X078845IV0) funded by the Ministry of Economy, Industry and Competitiveness (Spain) also supported this work. This work is based on the research supported in part by the National Research Foundation of South Africa (Grant Numbers 115300).

Acknowledgments: Most importantly we want to thank all wonderful initiatives for participating in our study-without you, this study would not have possible. We acknowledge the Chair in Agroecology and Food Systems of the University of Vic for the support during the fieldwork and contact with initiatives. Thanks also to Albert Norström for valuable comments during the thesis process.

Conflicts of Interest: The funders had no role in the design of the study; in the collection, analyses, or interpretation of data; in the writing of the manuscript, or in the decision to publish the results.

\section{References}

1. Rockström, J.; Stordalen, G.A.; Horton, R. Acting in the Anthropocene: The EAT- Lancet Commission. Lancet 2016, 387, 2364-2365. [CrossRef]

2. Willett, W.; Rockström, J.; Loken, B.; Springmann, M.; Lang, T.; Vermeulen, S.; Garnett, T.; Tilman, D.; DeClerck, F.; Wood, A.; et al. Food in the Anthropocene: The EAT-Lancet Commission on healthy diets from sustainable food systems. Lancet 2019, 6736, 3-49. [CrossRef]

3. FAO. Developing sustainable food systems and value chains for CSA Production. In Climate-Smart Agriculture; Sourcebook: Naperville, IL, USA, 2014.

4. West, P.C.; Gerber, J.S.; Engstrom, P.M.; Mueller, N.D.; Brauman, K.A.; Carlson, K.M.; Cassidy, E.S.; Johnston, M.; Macdonald, G.K.; Ray, D.K.; et al. Leverage points for improving global food security and the environment. Science 2014, 345, 325-328. [CrossRef] [PubMed]

5. Vermeulen, S.; Campbell, B.; Ingram, J. Climate Change and Food Systems. Annu. Rev. Environ. Resour. 2012, 37, 195-222. [CrossRef]

6. Allen, T.; Prosperi, P. Modeling sustainable food systems. Environ. Manag. 2016, 57, 956-975. [CrossRef] [PubMed]

7. Jackson, J.B.C.; Kirby, M.X.; Berger, W.H.; Bjorndal, K.A.; Botsford, L.W.; Bourque, B.J.; Bradbury, R.H.; Cooke, R.; Erlandson, J.; Estes, J.A.; et al. Historical overfishing and the recent collpase of coastal ecosystems. Science 2001, 293, 629-638. [CrossRef] [PubMed]

8. Gordon, L.J.; Bignet, V.; Crona, B.; Henriksson, P.J.G.; Holt, T. Van Rewiring food systems to enhance human health and biosphere stewardship. Environ. Res. Lett. 2017, 12, 100201. [CrossRef]

9. Rockström, J.; Steffen, W.; Noone, K.; Persson, Å.; Chapin, F.S.I.; Lambin, E.; Lenton, T.M.; Scheffer, M.; Folke, C.; Schellnhuber, H.-J.; et al. Planetary boundaries: Explorint the safe operating space for humanity. Ecol. Soc. 2009, 14, 1-32. [CrossRef]

10. Garnett, T. Planting up solutions. Science 2016, 353, 1202-1204. [CrossRef] [PubMed]

11. Cebolla-Cornejo, J.; Soler, S.; Nuez, F. Genetic erosion of traditional varieties of vegetable crops in Europe: Tomato cultivation in Valencia (Spain) as a case Study. Int. J. Plant Prod. 2007, 1, 113-128.

12. Migliorini, P.; Gkisakis, V.; Gonzalvez, V.; Raigón, M.D.; Bàrberi, P. Agroecology in mediterranean Europe: Genesis, state and perspectives. Sustainability 2018, 10, 2724. [CrossRef]

13. Stellmes, M.; Röder, A.; Udelhoven, T.; Hill, J. Mapping syndromes of land change in Spain with remote sensing time series, demographic and climatic data. Land Use Policy 2013, 30, 685-702. [CrossRef]

14. Olsson, P.; Galaz, V.; Boonstra, W.J. Sustainability transformations: A resilience perspective. Ecol. Soc. 2014, 19. [CrossRef]

15. Pereira, L.; Karpouzoglou, T.; Doshi, S.; Frantzeskaki, N. Organising a safe space for navigating social-ecological transformations to sustainability. Int. J. Environ. Res. Public Health 2015, 12, 6027-6044. [CrossRef] [PubMed]

16. Castellanos-Navarrete, A.; Jansen, K. Is Oil Palm Expansion a Challenge to Agroecology? Smallholders Practising Industrial Farming in Mexico. J. Agric Chang. 2018, 18, 132-155. [CrossRef]

17. Wezel, A.; Bellon, S.; Doré, T.; Francis, C.; Vallod, D.; David, C. Variation partitioning of taxa data matrices: Estimation and comparison of fractions. Agron. Sustain. Dev. 2009, 29, 503-515. [CrossRef]

18. Pimbert, M.P.; Lemke, S. Using agroecology to enhance dietary diversity. UNSCN News: Advancing Equity, Equality and Non-Discrimination in Food Systems: Pathways to Reform. Available online: https: / www.unscn. org/uploads/web/news/UNSCN-News43-WEB.pdf (accessed on 22 February 2019).

19. Berkes, F. Sacred Ecology, 2nd ed.; Routledge: Abingdon, UK, 2008; ISBN 0203928954. 
20. Berkes, F.; Colding, J.; Folke, C. Rediscovery of Traditional Ecological Knowledge as Adaptive Management. Ecol. Appl. 2000, 10, 1251-1262. [CrossRef]

21. Nugraha, A. Transforming Tradition for Sustainability. In Proceedings of the Joining Forces-International Conference on Design Research, Helsinki, Finland, 22-24 September 2005; University of Art and Design Helsinki: Helsinks, Finland, 2005.

22. Cannarella, C.; Piccioni, V. Traditiovations: Creating innovation from the past and antique techniques for rural areas. Technovation 2011, 31, 689-699. [CrossRef]

23. Mgbeoji, I. Making Space for Grandma: The Emancipation of Traditional Knowledge and the Dominance of Western-Style Intellectual Property Rights Regimes. Comp. Res. Law Polit. Econ. Res. Pap. 2010. [CrossRef]

24. Téllez-Muñoz, V.; Zografos-Johnsson, D. Traditional Knowledge as a Source for Innovation. In Intellectual Property, Trade and Development; Gervais, D.J., Ed.; Oxford University Press: Oxford, UK, 2014; pp. 314-327.

25. FAO. FAO and Traditional Knowledge: The Linkages with Sustainability, Food Security and Climate Change Impacts; FAO: Rome, Italy, 2009; Volume 16.

26. Calvet-Mir, L.; Benyei, P.; Aceituno-Mata, L.; Pardo-de-Santayana, M.; López-García, D.; Carrascosa-García, M.; Perdomo-Molina, A.; Reyes-García, V. The contribution of traditional agroecological knowledge as a digital commons to agroecological transitions: The case of the CONECT-e platform. Sustainability 2018, 10, 3214. [CrossRef]

27. Olsson, P.; Moore, M.-L.; Westley, F.R.; McCarthy, D.D.P. The concept of the Anthropocene as a game-changer: A new context for social innovation and transformations to sustainability. Ecol. Soc. 2017, 22, 31. [CrossRef]

28. Olsson, P.; Galaz, V. Social-Ecological Innovation and Transformation. In Social Innovation; Nicholls, A., Murdock, A., Eds.; Palgrave Macmillan: Basingstoke, UK, 2011; p. 25.

29. Francis, C.; Lieblein, G.; Gliessman, S.; Breland, T.A.; Creamer, N.; Harwood, R. Agroecology: The Ecology of Food Systems. J. Sustain. Agric. 2003, 22, 37-41. [CrossRef]

30. Howard-Borjas, P.L.; Cuijpers, W. Gender and the Management and Conservation of Plant Biodiversity; Deutsche Gesellschaft für Technische Zusammenarbeit: Bonn, Germany, 2013.

31. García-González, Á.; Achón, M.; Alonso-Aperte, E.; Varela-Moreiras, G. Identifying factors related to food agency: Cooking habits in the Spanish adult population-A cross-sectional study. Nutrients 2018, 10, 217. [CrossRef] [PubMed]

32. Jallinoja, P.; Niva, M.; Latvala, T. Future of sustainable eating? Examining the potential for expanding bean eating in a meat-eating culture. Futures 2016, 83, 4-14. [CrossRef]

33. Hernández-Morcillo, M.; Hoberg, J.; Oteros-Rozas, E.; Plieninger, T.; Gómez-Baggethun, E.; Reyes-García, V. Traditional Ecological Knowledge in Europe: Status Quo and Insights for the Environmental Policy Agenda. Environ. Sci. Policy Sustain. Dev. 2014, 56, 3-17. [CrossRef]

34. Burlingame, B.; Dernini, S. Sustainable diets: The Mediterranean diet as an example. Public Health Nutr. 2011, 14, 2285-2287. [CrossRef] [PubMed]

35. Otero, I.; Boada, M.; Tàbara, J.D. Social-ecological heritage and the conservation of Mediterranean landscapes under global change. A case study in Olzinelles (Catalonia). Land Use Policy 2013, 30, 25-37. [CrossRef]

36. Silva Pérez, R. Agricultura, paisaje y patrimonio territorial. Los paisajes de la agricultura. Boletín de la Asociación de Geógrafos Españoles 2009, 49, 309-334.

37. Pereira, L.M.; Wynberg, R.; Reis, Y. Agroecology: The Future of Sustainable Farming? Environ. Sci. Policy Sustain. Dev. 2018, 60, 4-17. [CrossRef]

38. Gómez-Baggethun, E.; Reyes-García, V.; Olsson, P.; Montes, C. Traditional ecological knowledge and community resilience to environmental extremes: A case study in Doñana, SW Spain. Glob. Environ. Chang. 2012, 22, 640-650. [CrossRef]

39. Dernini, S. The Erosion and the Renaissance of the Mediterranean Diet: A Sustainable Cultural Resource. Quaderns de la Mediterrania 2011, 16, 75-82.

40. Ansón, R.; Postigo, A. La Dieta Mediterránea en el Mundo. Available online: https://www.hola.com/estarbien/20180507123614/mejor-dieta-mediterranea/ (accessed on 22 February 2019).

41. Sáez-Almendros, S.; Obrador, B.; Bach-Faig, A.; Serra-Majem, L. Environmental footprints of Mediterranean versus Western dietary patterns: Beyond the health benefits of the Mediterranean diet. Environ. Health $A$ Glob. Access Sci. Source 2013, 12, 1-8. [CrossRef] [PubMed]

42. Gracia, A.; Albisu, L.M. Moving away from a typical Mediterranean diet: The case of Spain. Br. Food J. 1999, 101, 701-714. [CrossRef] 
43. Dernini, S.; Berry, E.M. Mediterranean diet: From a healthy to a sustainable dietary pattern. Front. Nutr. 2015, 2, 1-7. [CrossRef] [PubMed]

44. Padilla, M. Dietary patterns and trends in consumption. In The Future of Agriculture and Food in Mediterranean Countries; CIHEAM-Presses de Sciences Po.: Paris, France, 2008; pp. 149-170.

45. Muñoz-Pradas, F. Consumer Populations and Nutritional Transition in Spain in the Twentieth Century. Histoire Mesure 2011, 26, 131-173. [CrossRef]

46. Bach-Faig, A.; Fuentes-Bol, C.; Ramos, D.; Carrasco, J.L.; Roman, B.; Bertomeu, I.F.; Cristià, E.; Geleva, D.; Serra-Majem, L. The Mediterranean diet in Spain: Adherence trends during the past two decades using the Mediterranean Adequacy Index. Public Health Nutr. 2011, 14, 622-628. [CrossRef] [PubMed]

47. Varela-Moreiras, G.; Ávila, J.M.; Cuadrado, C.; del Pozo, S.; Ruiz, E.; Moreiras, O. Evaluation of food consumption and dietary patterns in Spain by the Food Consumption Survey: Updated information. Eur. J. Clin. Nutr. 2010, 64, S37-S43. [CrossRef] [PubMed]

48. Medina, F.X. Food Culture in Spain; Greenwood Publishing Group: Westport, CT, USA, 2005; Volume 171.

49. Moreno, L.; Sarría, A.; Popkin, B. The nutrition transition in Spain: A European Mediterranean country. Eur. J. Clin. Nutr. 2002, 56, 992-1003. [CrossRef] [PubMed]

50. León-Muñoz, L.M.; Guallar-Castillón, P.; Graciani, A.; López-García, E.; Mesas, A.E.; Aguilera, M.T.; Banegas, J.R.; Rodríguez-Artalejo, F. Adherence to the Mediterranean Diet Pattern Has Declined in Spanish Adults. J. Nutr. 2012, 142, 1843-1850. [CrossRef] [PubMed]

51. FAO. Mediterranean Food Consumption Patterns. Diet, Environment, Society, Ecnomy and Health; FAO: Rome, Italy, 2015.

52. WHO. Country Profile: Spain. Nutrition, Physical Activity and Obesity; WHO: Geneva, Switzerland, 2013; pp. 3-7.

53. Rodríguez-Rodríguez, E.M.; Aparicio, A.; Aranceta-Bartina, J.; Gil, Á.; González-Gross, M.; Serra-Majem, L.; Varela-Moreiras, G.; Ortega, R. Low Adherence to Dietary Guidelines in Spain, Especially in the Overweight/ Obese Population: The ANIBES Study. J. Am. Coll. Nutr. 2016, 36, 240-247. [CrossRef] [PubMed]

54. van Dooren, C.; Kramer, G. Food Patterns and Dietary Recommendations in Spain, France and Sweden; WWF: Gland, Switzerland, 2012.

55. Instituto Geográfico Nacional España a Través De Los Mapas. Available online: http:/ /www.ign.es/espmap/ graficos_clima_bach.htm (accessed on 22 February 2019).

56. Instituto Nacional de Estadística Tasas de paro por Distintos Grupos de Edad, Sexo y Comunidad Autónoma. Available online: http:/ / www.ine.es/jaxiT3/Tabla.htm?t=4247 (accessed on 22 February 2019).

57. Bryman, A. Social Research Methods, 4th ed.; Oxford University Press: Oxford, UK, 2012.

58. Bennett, E.M.; Solan, M.; Biggs, R.; McPhearson, T.; Norström, A.V.; Olsson, P.; Pereira, L.; Peterson, G.D.; Raudsepp-Hearne, C.; Biermann, F.; et al. Bright spots: Seeds of a good Anthropocene. Front. Ecol. Environ. 2016, 14, 441-448. [CrossRef]

59. Pereira, L.; Bennett, E.; Biggs, R.O.; Peterson, G.; McPhearson, T.; Norström, A.; Olsson, P.; Preiser, R.; Raudsepp-Hearne, C.; Vervoort, J.M. Seeds of the future in the present: Exploring pathways for navigating towards "Good" Anthropocenes. In Urban Planet: Knowledge towards Sustainable Cities; Cambridge University Press: Cambridge, UK, 2018; pp. 327-350.

60. Srivastava, P.; Hopwood, N. A Practical Iterative Framework for Qualitative Data Analysis. Int. J. Qual. Methods 2009, 8, 76-84. [CrossRef]

61. Olsson, P.; Gunderson, L.H.; Carpenter, S.R.; Ryan, P.; Lebel, L.; Folke, C.; Holling, C.S. Shooting the rapids: Navigating transition to adaptive governance of social-ecological systems. Ecol. Soc. 2006, 11, 18. [CrossRef]

62. Folke, C.; Carpenter, S.R.; Walker, B.; Scheffer, M.; Chapin, T.; Rockstrom, J. Resilience Thinking: Integrating Resilience, Adapatability, and Transformability. Ecol. Soc. 2010, 15, 20. [CrossRef]

63. Hossain, M. Grassroots innovation: A systematic review of two decades of research. J. Clean. Prod. 2016, 137, 973-981. [CrossRef]

64. Moore, M.-L.; Riddell, D.; Vocisano, D. Scaling Out, Scaling Up, Scaling Deep: Strategies of Non-profits in Advancing Systemic Social Innovation. J. Corp. Citizsh. 2015, 2015, 67-84. [CrossRef]

65. Gómez-Cantó, C.M.; Martínez-Ruiz, M.P.; Izquierdo-Yusta, A. Food Values and the Spanish Consumer: Evidences Obtained in Different Segments. Nutr. Food Sci. 2018, 5, 555651.

66. FAO. UNEP Programme on Sustainable Food Systems (SFSP) of the 10-Year Framework of Programmes. Int. J. Integr. Care 2012, 1, 1-6. 
67. Pereira, L.M.; Hichert, T.; Hamann, M.; Preiser, R.; Biggs, R. Using futures methods to create transformative spaces: Visions of a good anthropocene in Southern Africa. Ecol. Soc. 2018, 23, 19. [CrossRef]

68. Abson, D.J.; Fischer, J.; Leventon, J.; Newig, J.; Schomerus, T.; Vilsmaier, U.; Von Wehrden, H.; Abernethy, P.; Ives, C.D.; Jager, N.W.; et al. Leverage points for sustainability transformation. Ambio 2017, 46, 30-39. [CrossRef] [PubMed]

69. Aschemann-Witzel, J.; Niebuhr Aagaard, E.M. Elaborating on the attitude-behaviour gap regarding organic products: Young Danish consumers and in-store food choice. Int. J. Consum. Stud. 2014, 38, 550-558. [CrossRef]

70. Kaiser, F.G.; Byrka, K.; Hartig, T. Reviving campbell's paradigm for attitude research. Personal. Soc. Psychol. Rev. 2010, 14, 351-367. [CrossRef] [PubMed]

71. Jaffee, D.; Howard, P.H. Corporate cooptation of organic and fair trade standards. Agric. Hum. Values 2010, 27, 387-399. [CrossRef]

72. Johnston, J.L.; Fanzo, J.C.; Bogil, B. Understanding Sustainable Diets: A Descriptive Analysis of the Determinants and Processes That Influence Diets and Their Impact on Health, Food Security and Environmental Sustainability. Adv. Nutr. 2014, 5, 418-429. [CrossRef] [PubMed]

73. Hunn, E. What is traditional ecological knowledge? In Traditional Ecological Knowledge: Wisdom for Sustainable Development; Williams, N., Baines, G., Eds.; Centre for Resource and Envrionmental Studies, Australian National University: Canberra, Australia, 1993; pp. 13-15.

74. Domfeh, K.A. Indigenous Knowledge Systems and the Need for Policy and Institutional Reforms. Tribes Tribals 2007, 1, 41-52.

75. Jauhiainen, J.S.; Hooli, L. Indigenous Knowledge and Developing Countries' Innovation Systems: The Case of Namibia. Int. J. Innov. Stud. 2017, 1, 89-106.

76. Monroe, M.; Day, B.; Grieser, M. GreenCOM weaves four strands. In Environmental Education $\mathcal{E}$ Communication for a Sustainable World: Handbook for International Practitioners; Academy for Educational Development: Washington, DC, USA, 2000; ISBN 0-89492-108-8.

77. Kollmuss, A.; Agyeman, J. Mind the Gap: Why do people act environmentally and what are the barriers to pro-environmental behavior? Environ. Educ. Res. 2002, 239-260. [CrossRef]

78. Piñeiro, C. En el Jardín de la Comunciación Ambiental: Aprendiendo del Diálogo. 2008, pp. $239-291$. Available online: https:/ / dialnet.unirioja.es/servlet/articulo?codigo=2740999 (accessed on 22 February 2019).

79. Tengö, M.; Hill, R.; Malmer, P.; Raymond, C.M.; Spierenburg, M.; Danielsen, F.; Elmqvist, T.; Folke, C. Weaving knowledge systems in IPBES, CBD and beyond-Lessons learned for sustainability. Curr. Opin. Environ. Sustain. 2017, 26-27, 17-25. [CrossRef]

(C) 2019 by the authors. Licensee MDPI, Basel, Switzerland. This article is an open access article distributed under the terms and conditions of the Creative Commons Attribution (CC BY) license (http://creativecommons.org/licenses/by/4.0/). 